\title{
Modelling of Adsorption of Methane, Nitrogen, Carbon Dioxide, Their Binary Mixtures, and Their Ternary Mixture on Activated Carbons Using Artificial Neural Network
}

https://doi.org/10.15255/KUI.2019.002

KUI-18/2019

Original scientific paper

Received January 18, 2019

Accepted March 8, 2019

\author{
H. Barki, L. Khaouane, ${ }^{*}$ and S. Hanini \\ Laboratory of Biomaterial and Transport Phenomena (LBMPT), University of Médéa, Algeria
}

This work is licensed under a Creative Commons Attribution 4.0 International License

\begin{abstract}
This work examines the use of neural networks in modelling the adsorption process of gas mixtures $\left(\mathrm{CO}_{2}, \mathrm{CH}_{4}\right.$, and $\left.\mathrm{N}_{2}\right)$ on different activated carbons. Seven feed-forward neural network models, characterized by different structures, were constructed with the aim of predicting the adsorption of gas mixtures. A set of $417,625,143,87,64,64$, and 40 data points for NN1 to NN7, respectively, were used to test the neural networks. Of the total data, $60 \%, 20 \%$, and $20 \%$ were used, respectively, for training, validation, and testing of the seven models. Results show a good fit between the predicted and experimental values for each model; good correlations were found $(R=0.99656$ for NN1, $R=0.99284$ for NN2, $R=0.99388$ for NN3, $R=0.99639$ for $Q_{1}$ for NN4, $R=0.99472$ for $Q_{2}$ for $N N 4, R=0.99716$ for $Q_{1}$ for $N N 5, R=0.99752$ for $Q_{3}$ for $N N 5, R=0.99746$ for $Q_{2}$ for NN6, $R=0.99783$ for $Q_{3}$ for NN6, $R=0.9946$ for $Q_{1}$ for NN7, $R=0.99089$ for $Q_{2}$ for NN7, and $R=0.9947$ for $Q_{3}$ for NN7). Moreover, the comparison between the predicted results and the classical models (Gibbs model, Generalized dual-site Langmuir model, and Ideal Adsorption Solution Theory) shows that the neural network models gave far better results.
\end{abstract}

Keywords

Activated carbons, adsorption, gas mixture, modelling, neural network

\section{Introduction}

Most applications of solids in industry involve porous materials and adsorption processes. ${ }^{1}$ Multicomponent adsorption equilibrium is the theoretical basis of designing a separation process based on adsorption. ${ }^{2,3}$ It is a process whereby two or more components of a fluid (gas or liquid) stream are separated through contact with a solid surface. The quantity of the component that is able to bind to the surface of the adsorbent will depend on the temperature and the composition (partial pressure or concentration), as well as various physical and chemical properties of the adsorbate-adsorbent pair. A measurement of the amount adsorbed over a range of compositions at a fixed temperature is known as an adsorption isotherm. ${ }^{4}$

Adsorption represents an important process for separation and purification processes within many domains of the chemical industry. ${ }^{5,6}$ Adsorption has been widely used in environmental chemistry because of its relatively low cost, simplicity of design, and capacity for adsorbing a board range of pollutants at low concentration. ${ }^{7,8}$ Gas adsorption is of particular interest especially because it is involved in numerous processes linked to environmental protection. ${ }^{9}$ Activated carbon is the most commonly used and most effective modified adsorbent support because of its high specific surface area, ${ }^{10}$ low acid/base reactivity, thermodynamically stable nature, and porous structure with high controllability, ${ }^{11,12}$ compared to other adsorbents such as zeolite and silica. ${ }^{13-15}$ Moreover, it can be produced in large quantities inexpensively. ${ }^{11,16}$

${ }^{*}$ Corresponding author: Latifa Khaouane, Doctor

Email: latifa_khaouane@yahoo.fr
An accurate assessment of the equilibrium and kinetics of adsorption is very important for the design and operation of adsorption-based processes. ${ }^{1}$ A number of models to predict the adsorption equilibria have been proposed by many investigators ${ }^{17}$ such as Langmuir model, ${ }^{18}$ Freundlich model, ${ }^{19}$ Sips model, ${ }^{20}$ and Toth model. ${ }^{21}$ These models are used to predict only the adsorption of the pure component system. Therefore, mathematical models have been developed to predict multicomponent adsorption equilibrium based on the adsorption information of each component. ${ }^{22-25}$ These models are roughly classified into five groups: (1) extended Langmuir (EL) model; (2) ideal adsorption solution theory; ${ }^{26}$ (3) vacancy solution theory; ${ }^{27-29}$ (4) statistical thermodynamic model; ${ }^{30,31}$ (5) Polanyi potential theory; ${ }^{32}$ and other classical models. Each model had some degree of success, and was limited to a few specific systems. ${ }^{2}$ To avoid these limitations, the application of assumption-free models is proposed. M. Hasanzadeh et al. ${ }^{33}$ propose a new simplified local density model for adsorption of pure gases and binary mixtures on activated carbon. It was shown that the new SLD model can correlate adsorption data for different pressures and temperatures with minimum error. ${ }^{33}$ Arpita Ghosh et al. ${ }^{34}$ propose the modelling of biosorption of $\mathrm{Cu}$ (II) by alkali-modified spent tea leaves using response surface methodology (RSM) and artificial neural network (ANN). ${ }^{34}$ ANN is one of the data-based non-traditional tools for modelling the adsorption process. ANN modelling has been successfully used for the adsorption process in the past decade. ${ }^{35}$ Feedforward neural networks have been successfully used in many applications related to adsorption. It has been used to simulate the dynamics of an adsorption column for wastewater treatment of water containing toxic chemicals. ${ }^{36}$ Kumar et al. ${ }^{37}$ 
used a three-layer feedforward artificial neural network to model the equilibrium data of hydrogen onto activated carbons, ${ }^{37}$ the properties of the activated carbons and the experimental conditions were used as inputs to predict the corresponding hydrogen uptake at equilibrium conditions. ${ }^{4}$ Cojocaru et al. ${ }^{38}$ constructed a feedforward artificial neural network to predict the removal efficiency of an oil slick from the water surface by peat sorbent. Adsorbent dose, drainage time, and the initial thickness of the oil slick were used as inputs of the neural network to predict the removal efficiency as output. The mean square error (MSE) value of the network was found to be $4.979 \cdot 10^{-4} \cdot{ }^{38}$ Aghav et al. ${ }^{39}$ used a three-layer feedforward neural network with back propagation algorithm for estimation of removal efficiencies of phenol and resorcinol, in bi-solute water, by some carbonaceous adsorbents. ${ }^{39}$ The input parameters used for training the neural network include the amount of adsorbent, initial concentrations of phenol and resorcinol, contact time, and $\mathrm{pH}$. Removal efficiencies of phenol and resorcinol were considered as outputs of the neural network. ${ }^{35}$ With the artificial neural network, M. Molashahi et al. simulated the adsorption of methane on activated carbon. The input parameters of the applied ANN model were pressure, temperature, and surface area of the adsorbent, the performance of the ANN model was measured using mean square error as $3.053916 \cdot 10^{-3}$ and a correlation coefficient of $0.998 .{ }^{40}$

This study applied ANN models to predict the adsorption amount of pure gases $\left(\mathrm{CO}_{2}, \mathrm{CH}_{4}\right.$, and $\left.\mathrm{N}_{2}\right)$, their binary mixtures, and their ternary mixture, onto different activated carbons. For this purpose, a database of 1440 set was selected from different works in literature. Feedforward ANN models with BFGS algorithm was applied to predict the adsorption amount. The predicted results found from the optimized ANN models were compared with the experimental data in order to the find models that adequately predict equilibrium data.

\section{Experimental}

\subsection{Theory}

Artificial neural networks are analytical models capable of identifying logical patterns in sets of data that were developed to mathematically mimic the characteristics of biological neural networks. ${ }^{41}$ Artificial Neural Network (ANN) models were designed in the second half of the $20^{\text {th }}$ century by mathematical simulation of the procedures on which the human nervous system works. ${ }^{11,42,43}$ It consists of a number of interconnected simple processing units called artificial neurons. One of the most popular neural network paradigms applied to the modelling of a wide range of nonlinear systems, especially chemical and biological engineering processes, is the feedforward neural network (FFNN), ${ }^{44-46}$ which was used throughout this study with forecasting horizon and supervised learning.

ANNs are composed of neurons that are distributed between layers: one input layer, intermediate or hidden lay- ers, and one output layer. ${ }^{41,47}$ A single neuron computes the sum of its inputs, adds a bias term, and drives the result through a generally nonlinear activation function to produce a single output termed the activation level of the neuron. ${ }^{48}$ The input layer receives inputs $\left(x_{i}\right)$ from the real world and each succeeding layer receives weighted outputs $\left(w_{i j} \times x_{i}\right)$ from the preceding layer as its input, thus resulting in a feedforward artificial neural network (ANN), in which each input is fed forward to its succeeding layer where it is treated. The outputs of the previous layer constitute the outputs to the real world. ${ }^{49,50} \mathrm{~A}$ continuous multivariable function $F(x)$ is approached in the neural network by a selected function $f(x, w)$ for a fixed number of input variables

$$
x=\left(x_{0} ; x_{1}, \ldots, x_{1}\right)
$$

and $w$ is an array of weights, defined below. $x_{0}=1$ is the constant input, called bias, that is used to simulate thresholding effects in the neuron, and which also serves to simplify the mathematics; $x_{i}, i=1, \ldots, l$ are neural network inputs, and $I$ is the number of input nodes.

The output from the hidden layer is

$$
y=\left(y_{0} ; y_{1}, \ldots, y_{m}\right)
$$

where $y_{0}=1$ is the constant output from the bias neuron, $m$ is the number of processing elements in the hidden layer, and $y_{j}$ is output from the $j$-th processing element of the hidden layer.

$$
y_{j}=f\left(\sum_{i=0}^{1} w_{j i}^{0} x_{i}\right), j=1, \ldots, m
$$

$w_{j i}^{0}$ is a weight associated with a connection between the $i$-th processing element in the input layer and the $j$-th processing element in the hidden layer. For bias, the weight $w_{j 0}^{0}$ is taken as equal to 1 . The formula for the output layer of the neural network is like that in Eq. (3), only the signal from the bias neuron does not exist:

$$
z=\left(z_{1} ; z_{2}, \ldots, z_{n}\right)
$$

where

$$
z_{k}=f\left(\sum_{j=0}^{m} w_{k j}^{1} y_{j}\right), k=1, \ldots, n
$$

$n$ is the number of output neurons, and $w_{k j}^{1}$ is weight associated with a connection between the $j$-th processing element in the hidden layer and the $k$-th processing element in the output layer. For bias, the weight $w_{k 0}^{1}$ is again taken as equal to $1 .{ }^{51}$ The output is computed by means of a transfer function, also called the activation function. ${ }^{50}$

Hyperbolic tangent sigmoid transfer function:

$$
f(a)=\frac{e^{a}-e^{-a}}{e^{a}+e^{-a}}
$$


Logarithmic sigmoid transfer function:

$$
f(a)=\frac{1}{1+e^{-a}}
$$

Pure linear transfer function:

$$
f(a)=a
$$

The methodology of ANN application can be divided into three steps: training, validation, and generalization. During training, the synaptic and bias weights that were chosen randomly at the beginning of the training, are optimized using a set of data that can either be generated experimentally or it can originate from validated models. ${ }^{41,52}$ The only part of the available data is used for the training of the neural network. Different subsets of data are used for validating and generalizing the model previously trained. The efficiency of the ANN depends on several factors, like the number of neurons, the number of hidden layers, and the transfer function is chosen. Usually, the number of neurons in the input and output layers corresponds to the number of input and output variables. The number of neurons in the hidden layer must be chosen carefully, because on the one hand, networks with few neurons tend to have low precision, and on the other hand, an excessively high number of neurons can lead to overfitting which in turn results in problems of generalization of the model. ${ }^{41,53}$ The outputs from the output layer comprise a prediction of the dependent variables of the model. The network learns the relationships between the independent and dependent variables by iterative comparison of the predicted outputs and experimental outputs, and subsequent adjustment of the weight matrix and bias vector of each layer by a back-propagation training algorithm. Hence, the network progresses an NN model capable of predicting with acceptable accuracy the output variables lying within the model space defined by the training set. Consequently, the objective of ANN modelling is to minimize the prediction errors of validation data presented to the network after completion of the training step. ${ }^{50}$

\subsection{Modelling procedure}

A procedure based on the design and optimization of the architecture of the neural network was used, as described further:

- Data collection and division

- DB1 for pure $\mathrm{CO}_{2}$.

- DB2 for pure $\mathrm{CH}_{4}$.

- DB3 for pure $\mathrm{N}_{2}$.

- DB4 for $\left(\mathrm{CO}_{2}, \mathrm{CH}_{4}\right)$ binary mixture.

- DB5 for $\left(\mathrm{CO}_{2}, \mathrm{~N}_{2}\right)$ binary mixture.

- DB6 for $\left(\mathrm{CH}_{4}, \mathrm{~N}_{2}\right)$ binary mixture.

- DB7 for $\left(\mathrm{CO}_{2}, \mathrm{CH}_{4}\right.$, and $\left.\mathrm{N}_{2}\right)$ ternary mixture.

- Choice of parameters of neural networks.

- NN creation.

- Training algorithm (BFGS).
- Neurons in the hidden layer (3-20).

- Activation functions in the hidden and output layer (logsig, tansig, exponential, and purelin).

- Saving NN parameters.

\subsection{Database collection}

The collected data were imported from different works in the literature in order to study the adsorption phenomena of pure gases $\left(\mathrm{CO}_{2}, \mathrm{CH}_{4}\right.$, and $\left.\mathrm{N}_{2}\right)$, their binary mixtures, and their ternary mixtures on different activated carbons (Table 1). ${ }^{2,9,33,54-63}$

Table 1 - Experimental database

\begin{tabular}{c|c|c}
\hline Database & Samples & References \\
\hline DB1 & $\mathrm{CO}_{2}$ & $54,55,56,57,58,59,61,2,9,62$ \\
\hline DB2 & $\mathrm{CH}_{4}$ & $54,61,55,2,63,9,33$, \\
& $59,57,56,62,60$ \\
\hline DB3 & $\mathrm{N}_{2}$ & $54,55,33,57,60$ \\
\hline DB4 & $\left(\mathrm{CO}_{2}, \mathrm{CH}_{4}\right)$ & $54,55,9,62$ \\
\hline DB5 & $\left(\mathrm{CO}_{2}, \mathrm{~N}_{2}\right)$ & 54,55 \\
\hline DB6 & $\left(\mathrm{CH}_{4}, \mathrm{~N}_{2}\right)$ & 54,55 \\
\hline DB7 & $\left(\mathrm{CO}_{2}, \mathrm{CH}_{4}, \mathrm{~N}_{2}\right)$ & 54 \\
\hline
\end{tabular}

Table 2 - Database size

\begin{tabular}{c|c|c}
\hline Database (DB) & Neural Network & Database size \\
\hline DB1 & NN1 & 417 \\
\hline DB2 & NN2 & 625 \\
\hline DB3 & NN3 & 143 \\
\hline DB4 & NN4 & 87 \\
\hline DB5 & NN5 & 64 \\
\hline DB6 & NN6 & 64 \\
\hline DB7 & NN7 & 40 \\
\hline
\end{tabular}

For each database (DB1, DB2, DB3, DB4, DB5, DB6, and DB7) (Table 2), a set of input variables were identified. For DB1, DB2, and DB3, the inputs were the characteristics of activated carbons (specific surface area and micropore volume), and the operating conditions (temperature and pressure). For DB4, DB5, and DB6, the inputs were the average molar masses of mixtures, characteristics of activated carbons, and the operating conditions. The average molar masses of mixtures was calculated by the following equation:

$$
M=\sum_{i=1}^{n} x_{i} M_{i}
$$

where $M_{i}\left[\mathrm{~g} \mathrm{~mol}^{-1}\right]$ is the molar mass of component $i$, and $x_{i}$ is the molar fraction of component $i .{ }^{61}$ For DB7, the inputs 
were the average molar mass of mixture and the pressure. The outputs of DB1, DB2, and DB3 were the adsorption amounts of compounds $\left(Q_{1}\right.$ for $\left.\mathrm{CO}_{2}\right),\left(Q_{2}\right.$ for $\left.\mathrm{CH}_{4}\right)$, and $\left(Q_{3}\right.$ for $\mathrm{N}_{2}$ ); respectively. The outputs of DB4, DB5, and DB6 were the adsorption amounts of each compound: $\left(Q_{1}, Q_{2}\right)$ for DB4, $\left(Q_{1}, Q_{3}\right)$ for DB5, and $\left(Q_{2}, Q_{3}\right)$ for DB6. For DB7, the outputs were the adsorption amounts of each compound $\left(Q_{1}, Q_{2}\right.$, and $\left.Q_{3}\right)$. The values of standard deviations (STD) and mean for the inputs and outputs data are shown in (Table 3).

\subsection{Model development}

The samples were split randomly into three subsets: $60 \%$ for the training phase, $20 \%$ for the validation phase, and $20 \%$ for the test phase. The networks were trained us- ing the quasi-Newton BFGS (Broyden-Fletcher-Goldfarb-Shanno) algorithm (trainbfg). The FFNNs contained three layers of neurons or nodes: one input layer with four neurons for (NN1, NN2, and NN3), five neurons for (NN4, NN5, and NN6), two neurons for NN7, and one hidden layer with a number of active neurons optimized during training. In addition, one output layer with one neuron for (NN1, NN2, and NN3), two neurons for (NN4, NN5, and NN6), and three neurons for NN7. The number of hidden neurons varied from 3 to 20 neurons. The tangent sigmoid (tansig), the log sigmoid (logsig), the pure linear (purelin), and the exponential transfer functions were used in the hidden and the output layer.

The ANN modelling of the adsorption of gas mixtures on activated carbons was performed using STATISTICA software (version 8.0).

Table 3 - Statistical analysis of input and output data

\begin{tabular}{|c|c|c|c|}
\hline Data Bases & Inputs and outputs & STD & Mean \\
\hline $\begin{array}{c}\text { DB1 } \\
\text { Pure }\left(\mathrm{CO}_{2}\right)\end{array}$ & $\begin{array}{c}\text { specific surface area } / \mathrm{m}^{2} \mathrm{~g}^{-1} \\
\text { micropore volume } / \mathrm{cm}^{3} \mathrm{~g}^{-1} \\
T / \mathrm{K} \\
p / \mathrm{MPa} \\
Q_{1} / \mathrm{mmolg}^{-1}\end{array}$ & $\begin{array}{c}700.7141 \\
0.3445 \\
18.1164 \\
1.7845 \\
5.0907\end{array}$ & $\begin{array}{c}1364.90 \\
0.5817 \\
311.3843 \\
1.0175 \\
5.5306\end{array}$ \\
\hline $\begin{array}{c}\text { DB2 } \\
\text { Pure }\left(\mathrm{CH}_{4}\right)\end{array}$ & $\begin{array}{c}\text { specific surface area } / \mathrm{m}^{2} \mathrm{~g}^{-1} \\
\text { micropore volume } / \mathrm{cm}^{3} \mathrm{~g}^{-1} \\
T / \mathrm{K} \\
p / \mathrm{MPa} \\
\mathrm{Q}_{2} / \mathrm{mmolg}^{-1}\end{array}$ & $\begin{array}{c}465.9869 \\
0.1911 \\
25.6785 \\
1.9516 \\
2.1273\end{array}$ & $\begin{array}{c}1211.40 \\
0.4971 \\
305.5740 \\
1.0565 \\
2.4958\end{array}$ \\
\hline $\begin{array}{c}\text { DB3 } \\
\text { Pure }\left(\mathrm{N}_{2}\right)\end{array}$ & $\begin{array}{c}\text { specific surface area } / \mathrm{m}^{2} \mathrm{~g}^{-1} \\
\text { micropore volume } / \mathrm{cm}^{3} \mathrm{~g}^{-1} \\
T / \mathrm{K} \\
p / \mathrm{MPa} \\
Q_{3} / \mathrm{mmolg}^{-1}\end{array}$ & $\begin{array}{c}309.0018 \\
0.0863 \\
11.0189 \\
3.8065 \\
1.2209\end{array}$ & $\begin{array}{c}861.1189 \\
0.3957 \\
315.8290 \\
2.4823 \\
1.4928\end{array}$ \\
\hline $\begin{array}{c}\mathrm{DB} 4 \\
\underset{\text { mixture }}{\left(\mathrm{CO}_{2}-\mathrm{CH}_{4}\right) \text { binary }} \\
\text { mixture }\end{array}$ & $\begin{array}{c}\text { specific surface area } / \mathrm{m}^{2} \mathrm{~g}^{-1} \\
\text { micropore volume } / \mathrm{cm}^{3} \mathrm{~g}^{-1} \\
\text { average molar mass } / \mathrm{g} \mathrm{mol}^{-1} \\
T / \mathrm{K} \\
p / \mathrm{MPa} \\
Q_{1} / \mathrm{mmolg}^{-1} \\
Q_{2} / \mathrm{mmolg}^{-1}\end{array}$ & $\begin{array}{c}213.6416 \\
0.1128 \\
6.2345 \\
14.9291 \\
3.5611 \\
2.6747 \\
1.3985\end{array}$ & $\begin{array}{c}1080 \\
0.4915 \\
29.5084 \\
314.5109 \\
4.050 \\
4.1178 \\
2.2096\end{array}$ \\
\hline $\begin{array}{c}\mathrm{DB} 5 \\
\left(\mathrm{CO}_{2}-\mathrm{N}_{2}\right) \text { binary } \\
\text { mixture }\end{array}$ & $\begin{array}{c}\text { specific surface area } / \mathrm{m}^{2} \mathrm{~g}^{-1} \\
\text { micropore volume } / \mathrm{cm}^{3} \mathrm{~g}^{-1} \\
\text { average molar mass } / \mathrm{g} \mathrm{mol}^{-1} \\
T / \mathrm{K} \\
p / \mathrm{MPa} \\
Q_{1} / \mathrm{mmolg}^{-1} \\
Q_{3} / \mathrm{mmolg}^{-1}\end{array}$ & $\begin{array}{l}201.0354 \\
0.1073 \\
3.8858 \\
9.8566 \\
3.7776 \\
2.9320 \\
0.7569\end{array}$ & $\begin{array}{c}1004.5 \\
0.4525 \\
36.1589 \\
310.6250 \\
4.9866 \\
4.6797 \\
1.0029\end{array}$ \\
\hline $\begin{array}{c}\mathrm{DB} 6 \\
\left(\mathrm{CH}_{4}-\mathrm{N}_{2}\right) \text { binary } \\
\text { mixture }\end{array}$ & $\begin{array}{c}\text { specific surface area } / \mathrm{m}^{2} \mathrm{~g}^{-1} \\
\text { micropore volume } / \mathrm{cm}^{3} \mathrm{~g}^{-1} \\
\text { average molar mass } / \mathrm{g} \mathrm{mol}^{-1} \\
T / \mathrm{K} \\
p / \mathrm{MPa} \\
Q_{2} / \mathrm{mmolg}^{-1} \\
Q_{3} / \mathrm{mmol} \mathrm{g}^{-1}\end{array}$ & $\begin{array}{l}201.0354 \\
0.1073 \\
2.9658 \\
9.8566 \\
3.7496 \\
1.6294 \\
0.8801\end{array}$ & $\begin{array}{c}1004.5 \\
0.4525 \\
22.3852 \\
310.6250 \\
4.9644 \\
2.6811 \\
1.2351\end{array}$ \\
\hline $\begin{array}{c}\mathrm{DB7} \\
\left(\mathrm{CO}_{2}-\mathrm{CH}_{4}-\mathrm{N}_{2}\right) \\
\text { ternary mixture }\end{array}$ & $\begin{array}{c}\text { average molar mass } / \mathrm{g} \mathrm{mol}^{-1} \\
\mathrm{p} / \mathrm{MPa}^{-1} \\
\mathrm{Q}_{1} / \mathrm{mmolg}^{-1} \\
\mathrm{Q}_{2} / \mathrm{mmolg}^{-1} \\
\mathrm{Q}_{3} / \mathrm{mmolg}^{-1}\end{array}$ & $\begin{array}{l}2.5605 \\
2.0303 \\
1.7813 \\
1.3327 \\
0.6007\end{array}$ & $\begin{array}{l}25.2276 \\
2.6867 \\
2.7056 \\
2.8153 \\
0.7464\end{array}$ \\
\hline
\end{tabular}


Table 4 - Structure of the optimized ANN model

\begin{tabular}{|c|c|c|c|c|c|c|}
\hline \multirow[b]{2}{*}{ NN models } & \multirow[b]{2}{*}{ Training algorithm } & \multirow{2}{*}{$\begin{array}{c}\text { Input layer } \\
\text { neuron } \\
\text { number }\end{array}$} & \multicolumn{2}{|c|}{ Hidden layer } & \multicolumn{2}{|c|}{ Output layer } \\
\hline & & & $\begin{array}{l}\text { neuron } \\
\text { number }\end{array}$ & $\begin{array}{l}\text { activation } \\
\text { function }\end{array}$ & $\begin{array}{l}\text { neuron } \\
\text { number }\end{array}$ & $\begin{array}{l}\text { activation } \\
\text { function }\end{array}$ \\
\hline NN1 & $\begin{array}{l}\text { BFGS algorithm quasi-Newton } \\
\text { (trainbfg) }\end{array}$ & 4 & 16 & Tansig & 1 & Tansig \\
\hline NN2 & $\begin{array}{c}\text { BFGS algorithm quasi-Newton } \\
\text { (trainbfg) }\end{array}$ & 4 & 17 & Tansig & 1 & Logsig \\
\hline NN3 & $\begin{array}{c}\text { BFGS algorithm quasi-Newton } \\
\text { (trainbfg) }\end{array}$ & 4 & 13 & Tansig & 1 & Tansig \\
\hline NN4 & $\begin{array}{l}\text { BFGS algorithm quasi-Newton } \\
\text { (trainbfg) }\end{array}$ & 5 & 13 & Tansig & 2 & Logsig \\
\hline NN5 & $\begin{array}{c}\text { BFGS algorithm quasi-Newton } \\
\text { (trainbfg) }\end{array}$ & 5 & 8 & Logsig & 2 & Identity \\
\hline NN6 & $\begin{array}{l}\text { BFGS algorithm quasi-Newton } \\
\text { (trainbfg) }\end{array}$ & 5 & 11 & Tansig & 2 & Identity \\
\hline NN7 & $\begin{array}{l}\text { BFGS algorithm quasi-Newton } \\
\text { (trainbfg) }\end{array}$ & 2 & 9 & Tansig & 3 & Tansig \\
\hline
\end{tabular}

\section{Results and discussion}

The definitive goal of this investigation was to test the ability of artificial neural network architectures with the least number of parameters to represent a wide variety of isotherm data. The input vectors had 417, 625, 143, 87, 64, 64,40 set of experimental data for NN1 to NN7; respectively. The input layers contain:

- Four neurons for (NN1, NN2, and NN3), representing the specific surface area and the micropore volume of activated carbons, temperature, and pressure.

- Five neurons for (NN4, NN5, NN6), representing average molar mass, specific surface area, and micropore volume of activated carbons, temperature, and pressure.

- Two neurons for NN7, representing the average molar mass of mixture, and pressure.

The output layer has one neuron for (NN1, NN2, and NN3), two neurons for (NN4, NN5, NN6), and three neurons for NN7. ANNs contain one hidden layer and feedforward was used for training the input data. The quasi-Newton's algorithm BFGS was used for estimating the parameters of the ANNs model. Table 4 shows the structure of the optimized NN models.

According to the previous discussion, seven neural network models were developed with the aim of predicting the adsorption of gases $\left(\mathrm{CO}_{2}, \mathrm{CH}_{4}\right.$, and $\left.\mathrm{N}_{2}\right)$ by activated carbons. Figs. 1-7 show a comparison between the predicted and experimental values of the outputs variables for the entire dataset by using the neural network models (NN1 to NN7). The plot and the parameters of the linear regression were obtained using the MATLAB function "plotregression". Figs. 1-7 show the agreement plots for the adsorption amount with agreement vectors approaching the ideal for the entire data set for NN1 to NN7, respectively.

- For NN1, $[\alpha, \beta, R]=[0.99,0.071,0.99656]$;

- For NN2, $[\alpha, \beta, R]=[0.97,0.083,0.99284]$;

- For NN3, $[\alpha, \beta, R]=[0.97,0.028,0.99388]$;
- For NN4, $[\alpha, \beta, R]=[0.99,0.11,0.99639]$ for $Q_{1}$ and $[\alpha, \beta, R]=[0.94,0.13,0.99472]$ for $Q_{2}$;

- For NN5, $[\alpha, \beta, R]=[1,0.015,0.99716]$ for $Q_{1}$ and $[\alpha$, $\beta, R]=[0.99,0.0096,0.99572]$ for $Q_{3}$;

- For NN6, $[\alpha, \beta, R]=[1,-0.00058,0.99746]$ for $Q_{2}$ and $[\alpha, \beta, R]=[1,0.0065,0.99783]$ for $Q_{3}$;

- For NN7, $[\alpha, \beta, R]=[0.97,0.041,0.9946]$ for $Q_{1}$ and $[\alpha, \beta, R]=[1,0.032,0.99089]$ for $Q_{2}$ and $[\alpha, \beta, R]=$ $[0.92,0.039,0.9947]$ for $Q_{3}$.

Most points are situated very near the diagonal. Figs. 1-7 show an excellent agreement between the experimental data and the ANNs predicted results for adsorption.

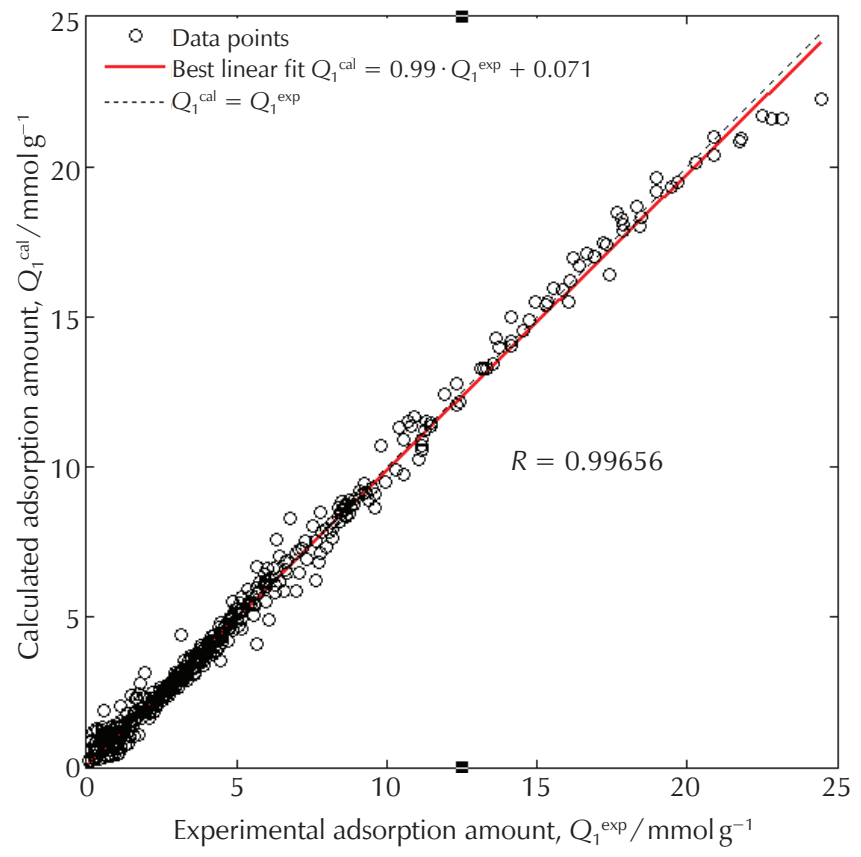

Fig. 1 - Comparison of experimental and calculated values for the entire data set of NN1 


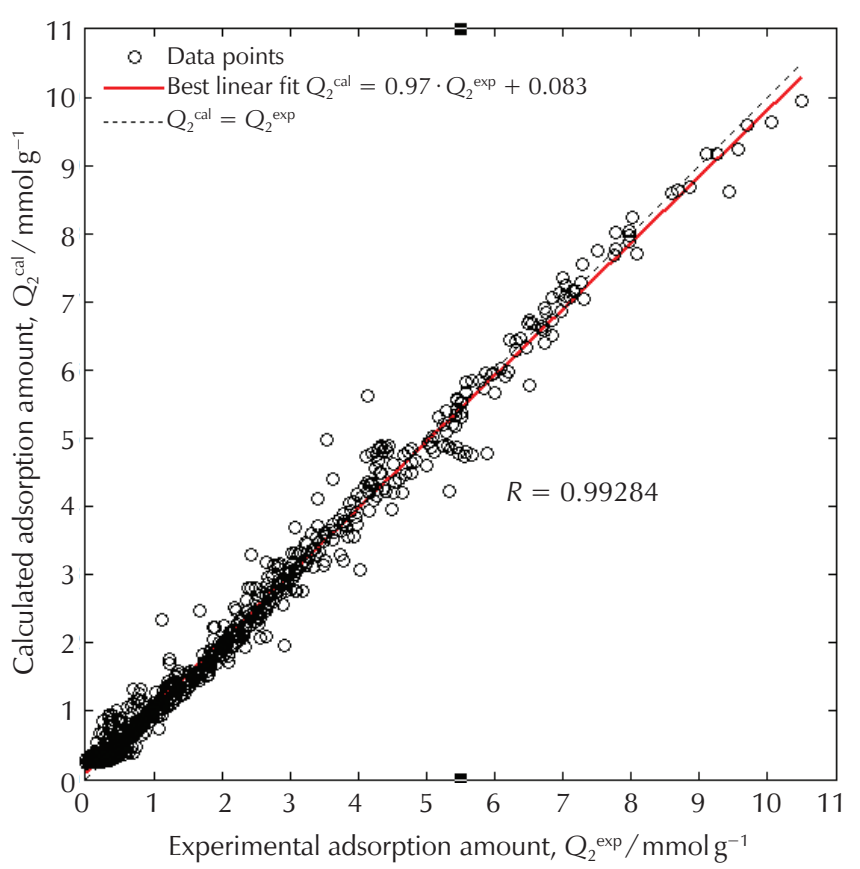

Fig. 2 - Comparison of experimental and calculated values for the entire data set of NN2

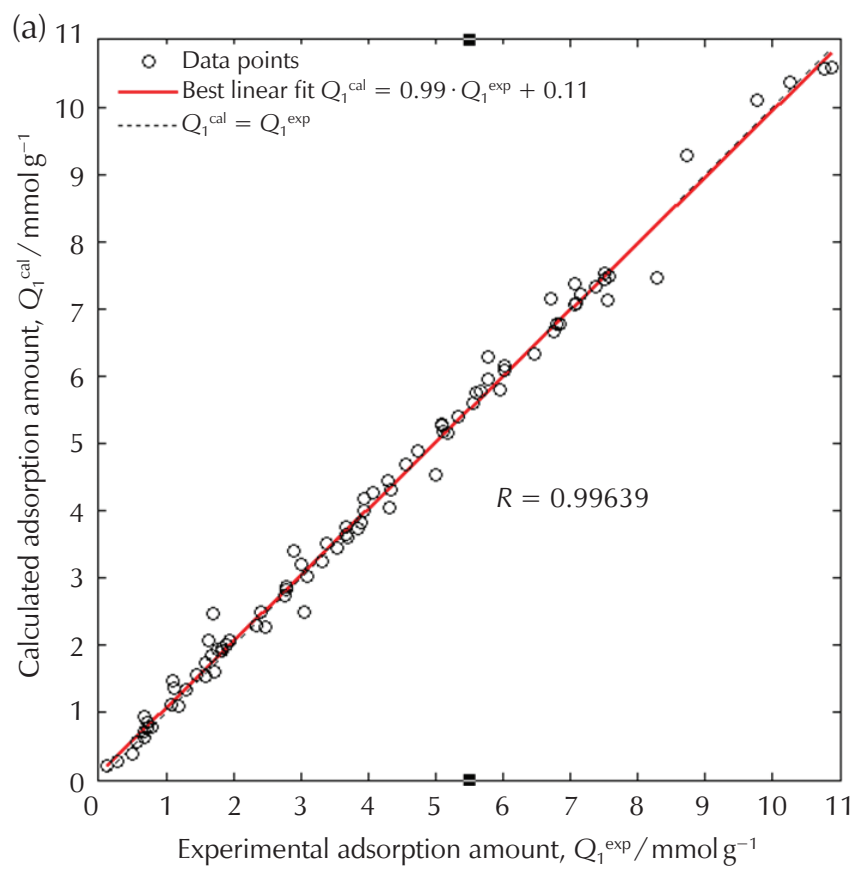

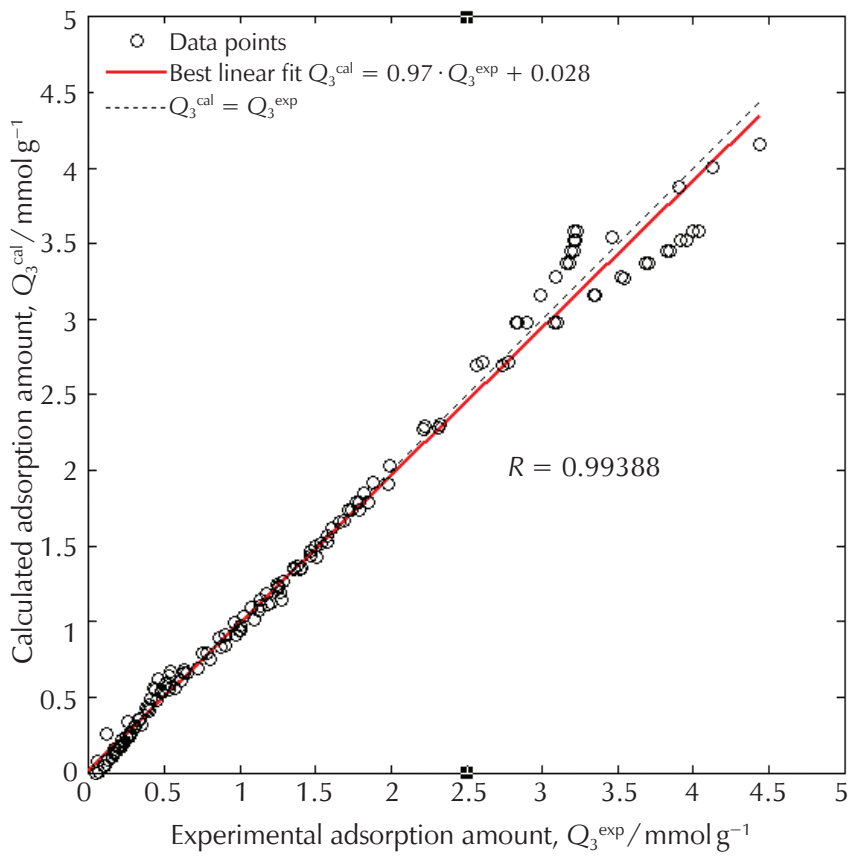

Fig. 3 - Comparison of experimental and calculated values for the entire data set of NN3

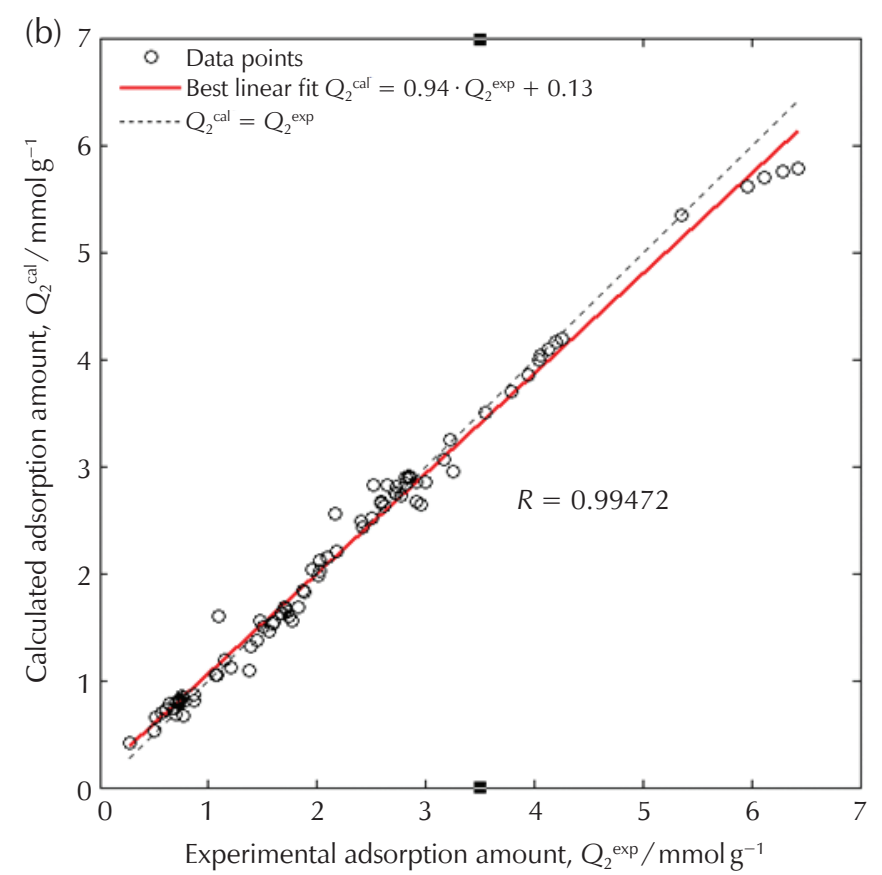

Fig. 4 - Comparison of experimental and calculated values for the entire data set of NN4 (a) $Q_{1}$, (b) $Q_{2}$ 
(a)

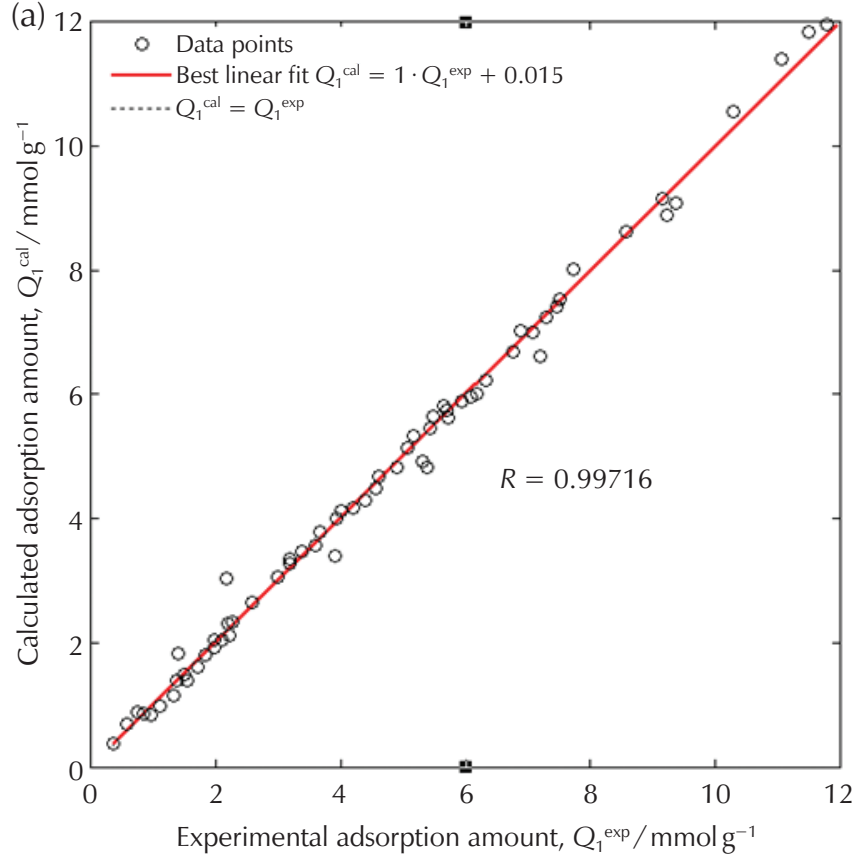

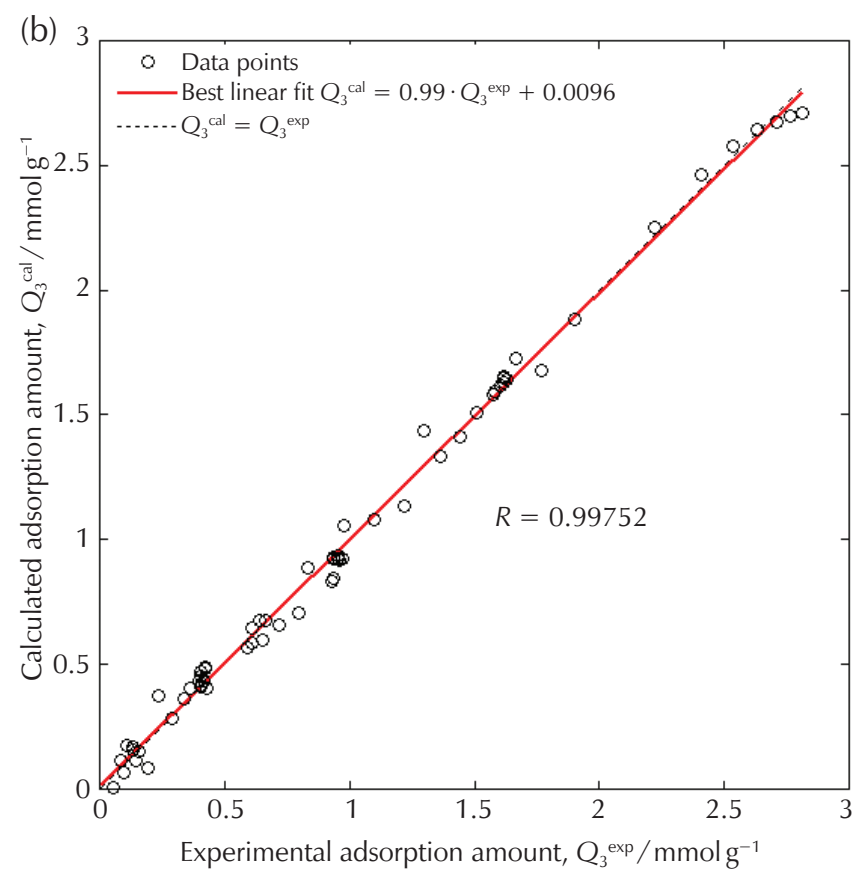

Fig. 5 - Comparison of experimental and calculated values for the entire data set of NN5 (a) $Q_{1}$, (b) $Q_{3}$
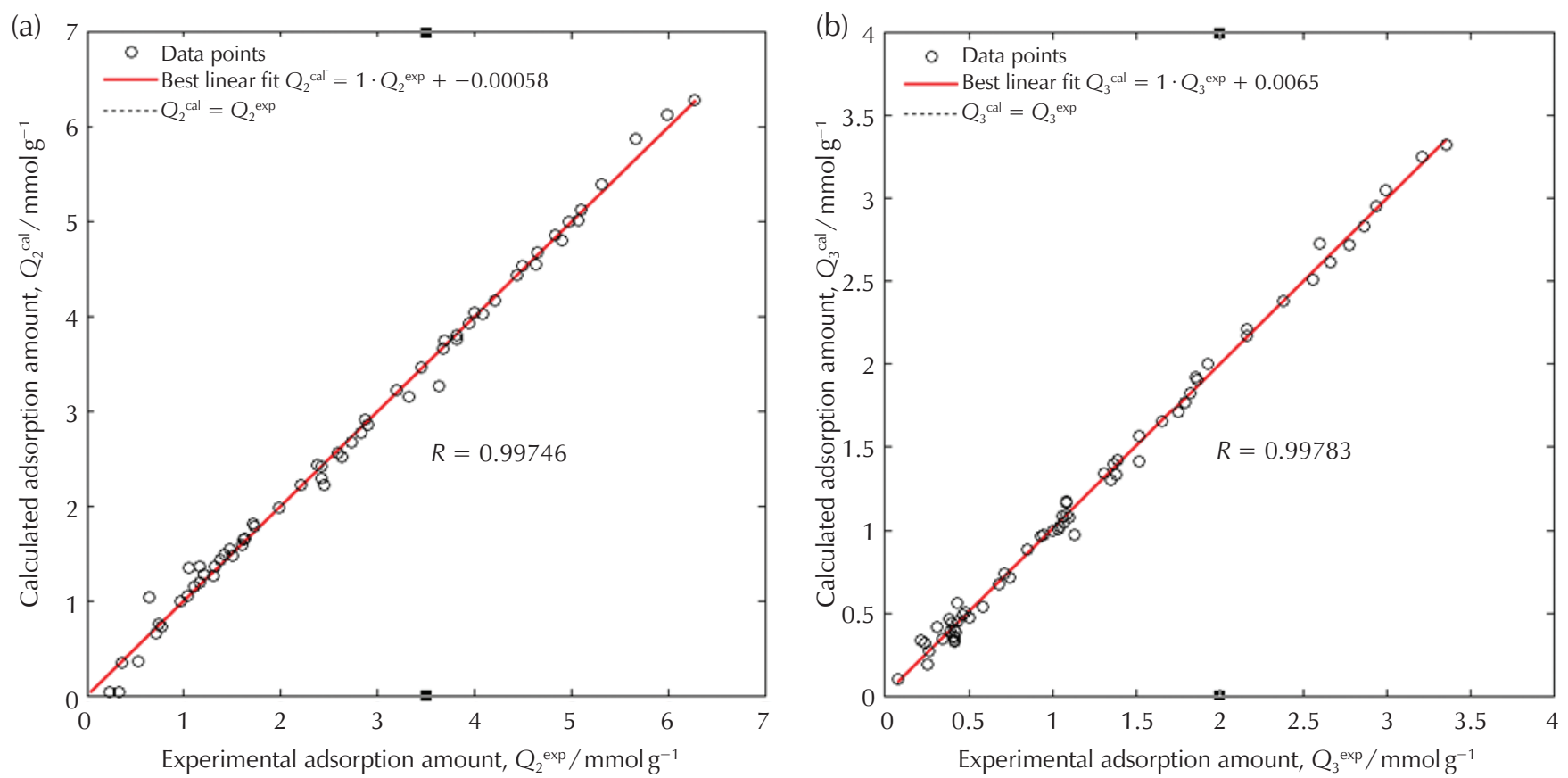

Fig. 6 - Comparison of experimental and calculated values for the entire data set of NN6 (a) $Q_{2}$, (b) $Q_{3}$ 

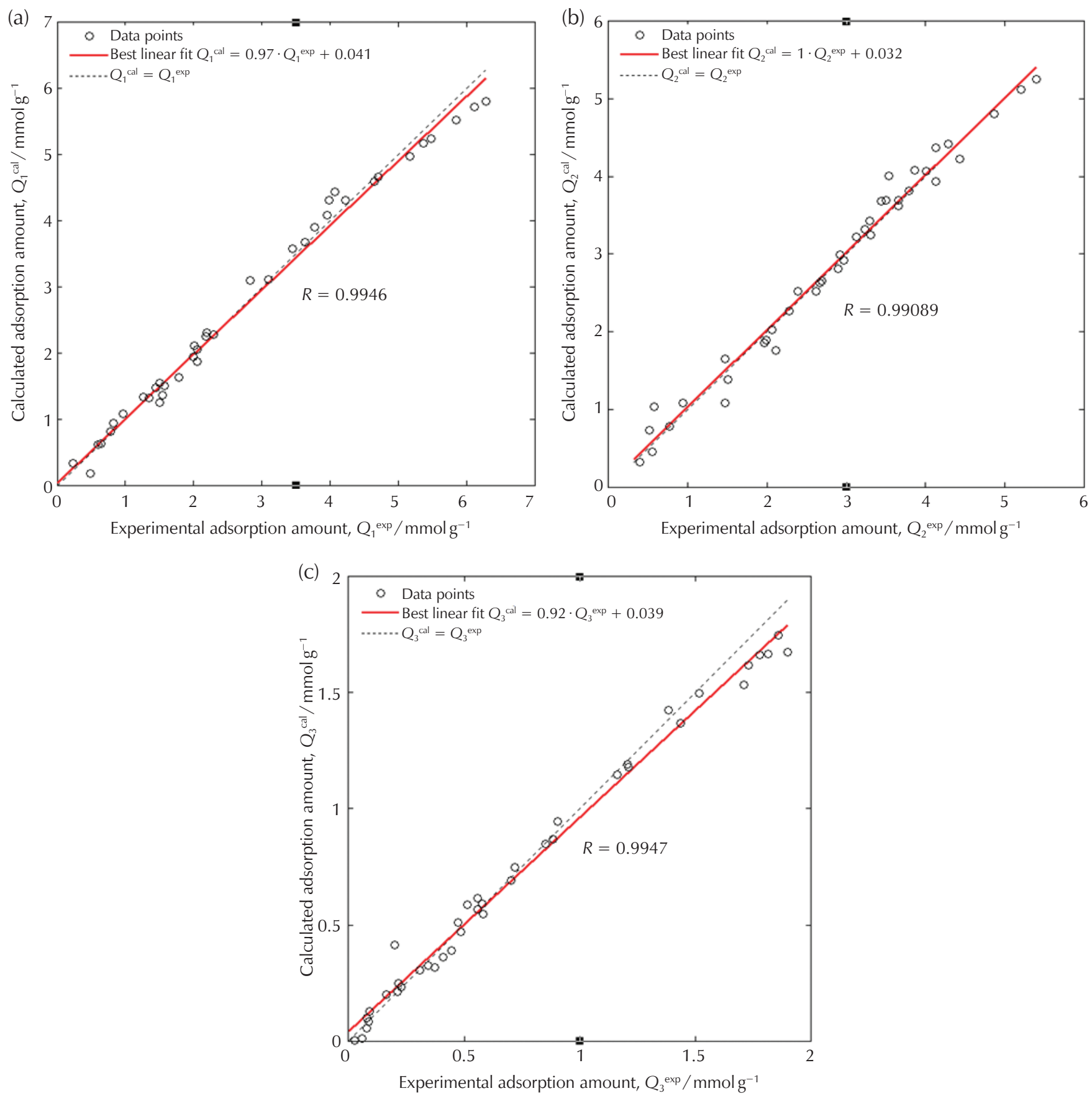

Fig. 7 - Comparison of experimental and calculated values for the entire data set of NN7 (a) $Q_{1}$, (b) $Q_{2}$, and (c) $Q_{3}$

Table 5 shows the vectors of linear regression for the neural models (NN1, NN2, NN3, NN4, NN5, NN6, and NN7). Clearly, the proposed neuronal approach gives satisfactory results with regression vector values approaching the ideal [i.e., $\alpha=1$ (slope), $\beta=0$ (y intercept), $R=1$ (correlation coefficient)] in the adjustment of the profiles of $Q_{1}, Q_{2}$, and $Q_{3}$.

The performances of various sub-models were estimated in terms of the root mean squared error (RMSE) criterion. The RMSE was calculated using Eq. (10). ${ }^{44}$

$$
\mathrm{RMSE}=\sqrt{\frac{\sum_{i=1}^{n}\left(Y_{i, \exp }-Y_{i, \mathrm{cal}}\right)^{2}}{n}}
$$

where $n$ is the total number of data points; $Y_{i, \text { exp }}$ is the experimental value, $Y_{i, \text { cal }}$ represents the calculated value from the neural network models. 
Table 5 - Linear regression vectors [linear equation: $Y^{\text {cal }}=\alpha Y^{\exp }+\beta$, with $\alpha=$ splote, $\beta=y$ intercept, $R=$ correlation coefficient]

\begin{tabular}{|c|c|c|c|c|c|c|}
\hline $\mathrm{NN}$ & Outputs & Datasets & $\alpha$ & $\beta$ & $R$ & RMSE \\
\hline NN1 & $Q_{1}$ & $\begin{array}{l}\text { training phase } \\
\text { validation phase } \\
\text { test phase } \\
\text { total }\end{array}$ & $\begin{array}{l}0.99 \\
0.97 \\
0.99 \\
0.99\end{array}$ & $\begin{array}{l}0.045 \\
0.14 \\
0.065 \\
0.077\end{array}$ & $\begin{array}{l}0.99716 \\
0.99553 \\
0.99604 \\
0.99656\end{array}$ & $\begin{array}{l}0.3802 \\
0.5344 \\
0.4194 \\
0.4229\end{array}$ \\
\hline NN2 & $Q_{2}$ & $\begin{array}{l}\text { training phase } \\
\text { validation phase } \\
\text { test phase } \\
\text { total }\end{array}$ & $\begin{array}{l}0.98 \\
0.97 \\
0.97 \\
0.97\end{array}$ & $\begin{array}{l}0.073 \\
0.12 \\
0.076 \\
0.083\end{array}$ & $\begin{array}{l}0.99322 \\
0.99038 \\
0.99422 \\
0.99284\end{array}$ & $\begin{array}{l}0.2472 \\
0.2943 \\
0.2394 \\
0.2558\end{array}$ \\
\hline NN3 & $Q_{3}$ & $\begin{array}{l}\text { training phase } \\
\text { validation phase } \\
\text { test phase } \\
\text { total }\end{array}$ & $\begin{array}{l}0.98 \\
0.95 \\
0.95 \\
0.97\end{array}$ & $\begin{array}{l}0.02 \\
0.03 \\
0.056 \\
0.028\end{array}$ & $\begin{array}{l}0.99407 \\
0.99566 \\
0.9925 \\
0.99388\end{array}$ & $\begin{array}{l}0.1333 \\
0.1143 \\
0.1631 \\
0.1363\end{array}$ \\
\hline \multirow{2}{*}{ NN4 } & $Q_{1}$ & $\begin{array}{l}\text { training phase } \\
\text { validation phase } \\
\text { test phase } \\
\text { total }\end{array}$ & $\begin{array}{c}0.98 \\
1 \\
0.99 \\
0.99\end{array}$ & $\begin{array}{l}0.077 \\
0.14 \\
0.18 \\
0.11\end{array}$ & $\begin{array}{l}0.99639 \\
0.99458 \\
0.99651 \\
0.99639\end{array}$ & $\begin{array}{l}0.2322 \\
0.2366 \\
0.2249 \\
0.2317\end{array}$ \\
\hline & $Q_{2}$ & $\begin{array}{l}\text { training phase } \\
\text { validation phase } \\
\text { test phase } \\
\text { total }\end{array}$ & $\begin{array}{l}0.96 \\
0.92 \\
0.91 \\
0.94\end{array}$ & $\begin{array}{l}0.078 \\
0.17 \\
0.17 \\
0.13\end{array}$ & $\begin{array}{l}0.99332 \\
0.99691 \\
0.99604 \\
0.99472\end{array}$ & $\begin{array}{l}0.1417 \\
0.1902 \\
0.1860 \\
0.1614\end{array}$ \\
\hline \multirow{2}{*}{ NN5 } & $Q_{1}$ & $\begin{array}{l}\text { training phase } \\
\text { validation phase } \\
\text { test phase } \\
\text { total }\end{array}$ & $\begin{array}{c}0.99 \\
1 \\
0.97 \\
1\end{array}$ & $\begin{array}{c}0.068 \\
-0.068 \\
0.07 \\
0.015\end{array}$ & $\begin{array}{l}0.99598 \\
0.99949 \\
0.99911 \\
0.99716\end{array}$ & $\begin{array}{l}0.2519 \\
0.1764 \\
0.1210 \\
0.2197 \\
\end{array}$ \\
\hline & $Q_{3}$ & $\begin{array}{l}\text { training phase } \\
\text { validation phase } \\
\text { test phase } \\
\text { total }\end{array}$ & $\begin{array}{c}0.99 \\
1 \\
0.98 \\
0.99\end{array}$ & $\begin{array}{l}0.0031 \\
0.025 \\
0.0047 \\
0.0096\end{array}$ & $\begin{array}{l}0.99705 \\
0.99786 \\
0.99875 \\
0.99752\end{array}$ & $\begin{array}{l}0.0531 \\
0.0563 \\
0.0492 \\
0.0530\end{array}$ \\
\hline \multirow{2}{*}{ NN6 } & $Q_{2}$ & $\begin{array}{l}\text { training phase } \\
\text { validation phase } \\
\text { test phase } \\
\text { total }\end{array}$ & $\begin{array}{c}0.98 \\
1.1 \\
0.99 \\
1\end{array}$ & $\begin{array}{l}0.036 \\
-0.17 \\
0.038 \\
-0.00058\end{array}$ & $\begin{array}{l}0.9966 \\
0.99883 \\
0.99987 \\
0.99746\end{array}$ & $\begin{array}{l}0.1278 \\
0.1240 \\
0.0360 \\
0.1155\end{array}$ \\
\hline & $Q_{3}$ & $\begin{array}{l}\text { training phase } \\
\text { validation phase } \\
\text { test phase } \\
\text { total }\end{array}$ & $\begin{array}{c}0.99 \\
1 \\
1 \\
1\end{array}$ & $\begin{array}{l}0.016 \\
0.0087 \\
-0.062 \\
0.0065\end{array}$ & $\begin{array}{l}0.99795 \\
0.99725 \\
0.99953 \\
0.99783\end{array}$ & $\begin{array}{l}0.0594 \\
0.0601 \\
0.0413 \\
0.0578\end{array}$ \\
\hline \multirow{3}{*}{ NN7 } & $Q_{1}$ & $\begin{array}{l}\text { training phase } \\
\text { validation phase } \\
\text { test phase } \\
\text { total }\end{array}$ & $\begin{array}{c}0.96 \\
1.1 \\
0.93 \\
0.97\end{array}$ & $\begin{array}{c}0.077 \\
-0.16 \\
0.15 \\
0.041\end{array}$ & $\begin{array}{c}0.99439 \\
0.99447 \\
0.99929 \\
0.9946\end{array}$ & $\begin{array}{l}0.1855 \\
0.2184 \\
0.1555 \\
0.1871\end{array}$ \\
\hline & $Q_{2}$ & $\begin{array}{l}\text { training phase } \\
\text { validation phase } \\
\text { test phase } \\
\text { total }\end{array}$ & $\begin{array}{c}0.99 \\
0.95 \\
1.4 \\
1\end{array}$ & $\begin{array}{l}0.027 \\
0.19 \\
-1 \\
0.032\end{array}$ & $\begin{array}{c}0.9967 \\
0.99069 \\
0.9951 \\
0.99089\end{array}$ & $\begin{array}{l}0.1106 \\
0.2250 \\
0.2711 \\
0.1794\end{array}$ \\
\hline & $Q_{3}$ & $\begin{array}{l}\text { training phase } \\
\text { validation phase } \\
\text { test phase } \\
\text { total }\end{array}$ & $\begin{array}{l}0.97 \\
0.88 \\
0.91 \\
0.92\end{array}$ & $\begin{array}{l}0.014 \\
0.091 \\
0.0022 \\
0.039\end{array}$ & $\begin{array}{c}0.9968 \\
0.99352 \\
0.99812 \\
0.9947\end{array}$ & $\begin{array}{l}0.0391 \\
0.1039 \\
0.1146 \\
0.0755\end{array}$ \\
\hline
\end{tabular}

\subsection{Comparisons between ANN models and classical models}

\subsubsection{Comparison between ANN models and the Gibbs model for the prediction of pure gases $\left(\mathrm{CO}_{2}, \mathrm{CH}_{4}\right.$ and $\mathrm{N}_{2}$ ) adsorption}

The Gibbs model was previously tested for predicting the adsorption of pure gases $\left(\mathrm{CO}_{2}, \mathrm{CH}_{4}\right.$, and $\left.\mathrm{N}_{2}\right)$ on activated carbon at $318.2 \mathrm{~K} .{ }^{55}$ Experimental results were compared with Gibbs model and ANN models in terms of the mean absolute error (MAE), the model predictive error (MPE), the root mean squared error (RMSE), and the standard error of prediction (SEP). The MAE, MPE, and SEP are defined as follows: ${ }^{64-67}$

$$
\mathrm{MAE}=\frac{1}{n} \sum_{i=1}^{n}\left|\left(y_{i, \text { exp }}-y_{i, \text { cal }}\right)\right|
$$




$$
\begin{gathered}
\operatorname{MPE}(\%)=\frac{100}{n} \sum_{i=1}^{n}\left|\frac{\left(y_{i, \text { exp }}-y_{i, \text { cal }}\right)}{y_{i, \text { exp }}}\right| \\
\operatorname{SEP}(\%)=\frac{\operatorname{RMSE}}{y_{\mathrm{e}}}
\end{gathered}
$$

where $n$ is the total number of data points; $y_{i, \text { exp }}$ is the experimental value, $y_{i, \text { cal }}$ is the calculated value from the neural network models or Gibbs model, and $Y_{e}$ is the mean value of experimental data.

Table 6 - Comparison of the NN models and the Gibbs model for the adsorption of pure gases

\begin{tabular}{c|c|c|c|c|c|c}
\hline \multirow{2}{*}{ Errors } & \multicolumn{2}{|c|}{$\mathrm{CO}_{2}$} & \multicolumn{2}{c|}{$\mathrm{CH}_{4}$} & \multicolumn{2}{c}{$\mathrm{N}_{2}$} \\
\cline { 2 - 7 } & \multicolumn{2}{|c}{$n=26$} & \multicolumn{2}{c}{$n=21$} & \multicolumn{2}{c}{$n=22$} \\
\cline { 2 - 7 } & $\mathrm{NN1}$ & Gibbs & NN2 & Gibbs & NN3 & Gibbs \\
\hline MPE & 1.6778 & 22.2812 & 8.8424 & 12.2306 & 6.2641 & 10.4138 \\
\hline RMSE & 0.1413 & 2.7507 & 0.4547 & 0.7817 & 0.2584 & 0.4535 \\
\hline SEP & 0.0196 & 0.3816 & 0.1009 & 0.1734 & 0.0850 & 0.1491 \\
\hline MAE & 0.1150 & 1.8792 & 0.3928 & 0.6289 & 0.2097 & 0.3690
\end{tabular}

Table 6 shows the comparison between NN models and the Gibbs model for the prediction of the adsorption isotherm of pure gases $\left(\mathrm{CO}_{2}, \mathrm{CH}_{4}\right.$, and $\left.\mathrm{N}_{2}\right)$. The $\mathrm{NN}$ models developed in this work for the adsorption of pure gases $\left(\mathrm{CO}_{2}, \mathrm{CH}_{4}\right.$, and $\left.\mathrm{N}_{2}\right)$, gave lower errors than the Gibbs model.

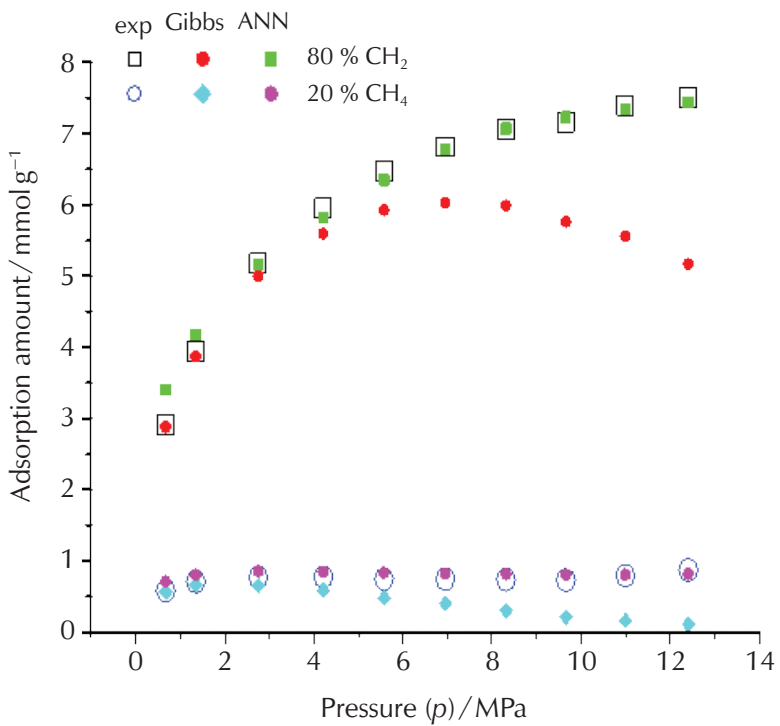

Fig. 9 - Nitrogen/ $\mathrm{CO}_{2}$ adsorption on dry activated carbon at 318.2 K. Prediction of the data with Gibbs isotherm and ANN.

\subsubsection{Comparison between ANN models and the Gibbs model for the prediction of binary mixtures $\mathrm{CO}_{2}$, $\left.\mathrm{CH}_{4}\right),\left(\mathrm{CO}_{2}, \mathrm{~N}_{2}\right)$, and $\left(\mathrm{CH}_{4}, \mathrm{~N}_{2}\right)$ adsorption}

Figs. 8-10 present the comparison between theory ( $\mathrm{NN}$ models, Gibbs model) and experimental data of the adsorption isotherms for temperature $T=318.2 \mathrm{~K}$ of binary mixtures $\left(\mathrm{CO}_{2}, \mathrm{CH}_{4}\right),\left(\mathrm{CO}_{2}, \mathrm{~N}_{2}\right)$, and $\left(\mathrm{CH}_{4}, \mathrm{~N}_{2}\right)$ in real units with composition of $(80,20),(80,20)$, and $(60,40)$, respectively. ${ }^{55}$ Figs. 8, 9, 10 show better agreement of experimental data with $\mathrm{NN}$ model than the Gibbs model.

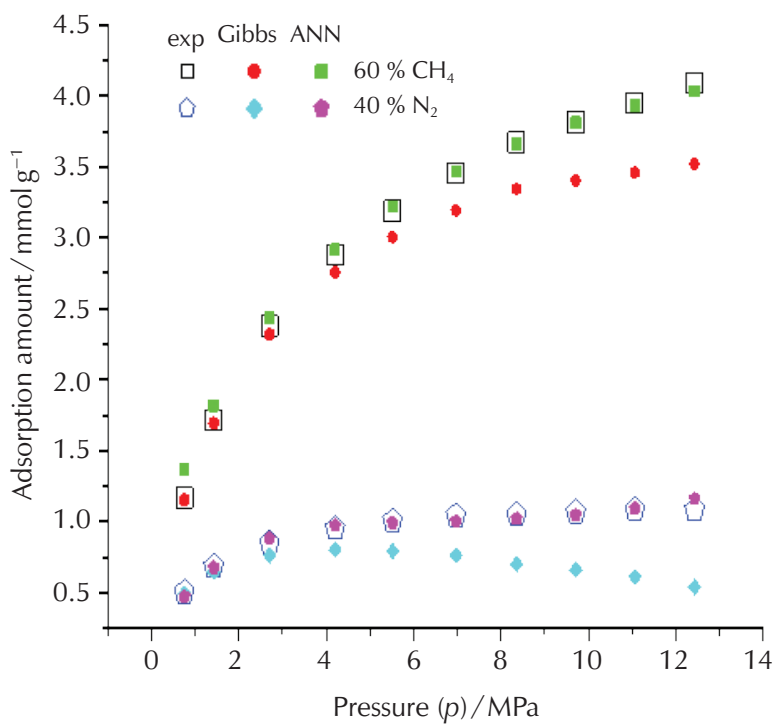

Fig. 8 - Methane/ $\mathrm{CO}_{2}$ adsorption on dry activated carbon at 318.2 K. Prediction of the data with Gibbs isotherm and ANN

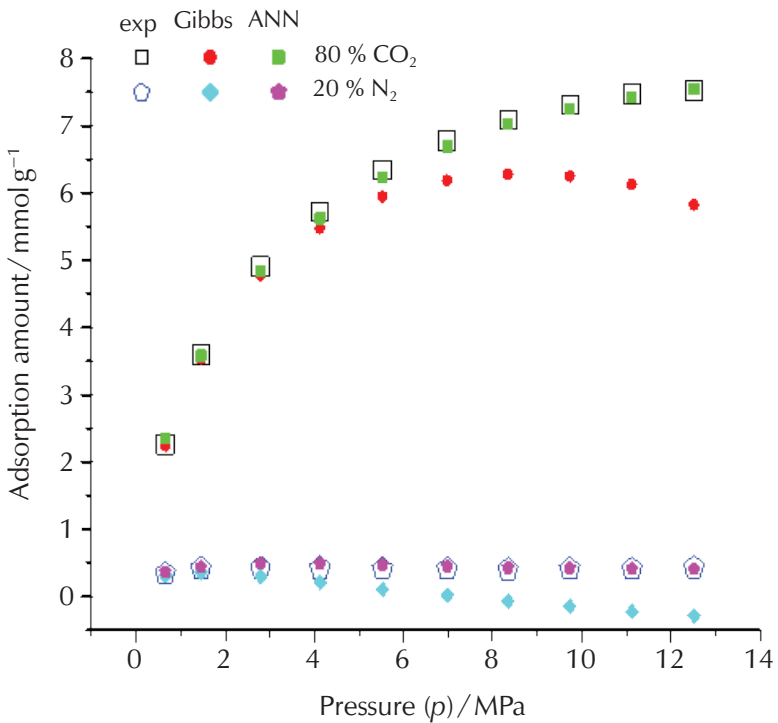

Fig. 10 - Methane/nitrogen adsorption on dry activated carbon at $318.2 \mathrm{~K}$. Prediction of the data with Gibbs isotherm and ANN. 


\subsubsection{Comparison between ANN model, the Generalized dual-site Langmuir model, and the IAST theory for the prediction of the adsorption of ternary mixture $\left(\mathrm{CO}_{2}, \mathrm{CH}_{4}\right.$, and $\left.\mathrm{N}_{2}\right)$}

The generalized dual-site Langmuir model and the IAST theory were previously tested for the prediction of the adsorption of ternary mixture $\left(\mathrm{CO}_{2}, \mathrm{CH}_{4}, \mathrm{~N}_{2}\right)$ by F. Dreisbach et al..$^{54}$ In this work, the comparison between models (generalized dual-site Langmuir model, IAST theory, and $\mathrm{NN}$ model) and the experimental data of the adsorption isotherm of the ternary mixture $\left(\mathrm{CO}_{2}, \mathrm{CH}_{4}\right.$, and $\left.\mathrm{N}_{2}\right)$ on activated carbon (AC) is presented. The mean relative deviations between the predicted $\left(n=n_{1}+n_{2}+n_{3}\right)$ and the experimental $\left(n_{\text {exp }}\right)$ total amounts adsorbed, as well as between the predicted $\left(x_{1}=n_{1} /\left(n_{1}+n_{2}+n_{3}\right)\right.$ and measured concentration $\left(x_{1, \text { exp }}\right)$ of component 1 in the ternary mixture are calculated as:

$$
\begin{aligned}
\Delta n & =\frac{1}{N} \sum_{i=1}^{N} \sqrt{\left(\frac{n_{\operatorname{expi}}-n_{i}}{n_{\text {exp }, i}}\right)^{2}} \\
\Delta x_{1} & =\frac{1}{N} \sum_{i=1}^{N} \sqrt{\left(\frac{x_{1, \text { expi }}-x_{1, i}}{x_{1, \text { exp }, i}}\right)^{2}}
\end{aligned}
$$

with $N$ being the total number of measurements. ${ }^{54}$ The resulting deviations are given in Table 7 .

Table 7 - Mean relative deviations between predicted and measured ternary gas mixture adsorption equilibria on the AC Norit R1 at $T=298 \mathrm{~K}$

\begin{tabular}{c|c|r|r}
\hline & $\begin{array}{c}\text { Generalized dual-site } \\
\text { Langmuir }\end{array}$ & IAST & ANN \\
\hline$\Delta n \%$ & 4.88 & 4.29 & 3.18 \\
\hline$\Delta x_{1} \%$ & 15.11 & 27.21 & 9.91 \\
\hline$\Delta x_{2} \%$ & 10.79 & 14.85 & 7.22 \\
\hline$\Delta x_{3} \%$ & 35.53 & 47.19 & 13.06 \\
\hline
\end{tabular}

The NN model developed in this work for the prediction of the adsorption of the ternary mixture $\left(\mathrm{CO}_{2}, \mathrm{CH}_{4}\right.$, and $\left.\mathrm{N}_{2}\right)$ gave lower errors than the generalized dual-site Langmuir model than IAST. This indicates that the neural network model is successful in the prediction of the ternary mixture of $\left(\mathrm{CO}_{2}, \mathrm{CH}_{4}\right.$, and $\left.\mathrm{N}_{2}\right)$ adsorption isotherm.

\section{Conclusion}

Artificial neural networks were proposed to model pure, binary, and ternary gas mixtures adsorption equilibriums.
Feedforward ANN models were applied to seven systems (pure $\mathrm{CO}_{2}, \mathrm{CH}_{4}, \mathrm{~N}_{2}$, their binary mixtures, and their ternary mixture). Of the total data, $60 \%, 20 \%$, and $20 \%$ were used, respectively, for training, validation, and testing of the seven models. The networks were trained using the quasi-Newton BFGS (Broyden-Fletcher-Goldfarb-Shanno) algorithm. The developed ANNs showed an accurate prediction of experimental data with root mean square errors of 0.4229 for NN1, 0.2558 for NN2, 0.1363 for NN3, 0.2317 for $Q_{1}$ for $N N 4,0.1614$ for $Q_{2}$ for $N N 4,0.2197$ for $Q_{1}$ for NN5, 0.0530 for $Q_{3}$ for NN5, 0.1155 for $Q_{2}$ for NN6, 0.0578 for $Q_{3}$ for NN6, 0.1871 for $Q_{1}$ for NN7, 0.1794 for $Q_{2}$ for NN7, and 0.0755 for $Q_{3}$ for NN7. In this study, the Gibbs model was also used to study the equilibrium data for pure $\left(\mathrm{CO}_{2}, \mathrm{CH}_{4}\right.$, and $\left.\mathrm{N}_{2}\right)$, and their binary mixtures. The generalized dual-site Langmuir model and the IAST theory were used to examine the equilibrium data of the ternary mixture of $\left(\mathrm{CO}_{2}, \mathrm{CH}_{4}\right.$, and $\left.\mathrm{N}_{2}\right)$. The comparison of the results of the ANNs models and classical models indicated that the ANN predicted gas adsorption on AC more accurately than the classical models over the full range of operating conditions.

\section{List of abbreviations}

AC - activated carbon

ANN - artificial neural network

BFGS - Broyden-Fletcher-Goldfarb-Shanno

Cal - calculated

DB - database

Exp - experimental

FFNN - feedforward neural network

IAST - Ideal adsorption solution theory

Logsig - logarithmic sigmoid transfer function

MAE - mean absolute error

MPE - model predictive error

MSE - mean square error

NN - neural network

Purelin - pure linear transfer function

$Q_{1} \quad$ - adsorption amount of $\mathrm{CO}_{2}$

$\mathrm{Q}_{2} \quad$ - adsorption amount of $\mathrm{CH}_{4}$

$Q_{3} \quad$ - adsorption amount of $\mathrm{N}_{2}$

$R \quad$ - correlation coefficient

RMSE - root mean squared error

RSM - response surface methodology

SEP - standard error of prediction

SLD - simplified local density

STD - standard deviations

Tansig - hyperbolic tangent sigmoid transfer function 


\section{References}

\section{Literatura}

1. N. Álvarez-Gutiérrez, M. V. Gil, F. Rubiera, C. Pevida, Kinetics of $\mathrm{CO}_{2}$ adsorption on cherry stone-based carbons in $\mathrm{CO}_{2} /$ $\mathrm{CH}_{4}$ separations, Chem. Eng. J. 307 (2017) 249-257, doi: https://doi.org/10.1016/j.cej.2016.08.077.

2. L. Zhou, J. Wu, M. Li, Q. Wu, Y. Zhou, Prediction of multicomponent adsorption equilibrium of gas mixtures including supercritical components, Chem. Eng. Sci. 60 (2005) 28332844, doi: https://doi.org/10.1016/j.ces.2004.11.058.

3. S. Qiao, K. Wang, X. Hu, Using local IAST with micropore size distribution to predict multicomponent adsorption equilibrium of gases in activated carbon, Langmuir. 16 (3) (2000) 1292-1298, doi: https://doi.org/10.1021/la990785q.

4. G. Morse, R. Jones, J. Thibault, F. H. Tezel, Neural network modelling of adsorption isotherms, Adsorption. 17 (2010) 303-309, doi: https://doi.org/10.1007/s10450-010-9287-1.

5. S. Beutekamp, P. Harting, Experimental determination and analysis of high pressure adsorption data of pure gases and gas mixtures, Adsorption. 8 (2002) 255-269, doi: https:// doi.org/10.1023/A:1021548112040.

6. C. J. King, Separation Processes, Center for Studies in Higher Education, 1980

7. 7. S. Rebouh, M. Bouhedda, S. Hanini, Neuro-fuzzy modeling of $\mathrm{Cu}(\mathrm{II})$ and $\mathrm{Cr}(\mathrm{VI})$ adsorption from aqueous solution by wheat straw, Desalin. Water Treat. 57 (14) (2016) 65156530, doi: https://doi.org/10.1080/19443994.2015.100917

8. A. Dong, J. Xie, W. Wang, L. Yu, Q. Liu, Y. Yin, A novel method for amino starch preparation and its adsorption for $\mathrm{Cu}(\mathrm{II})$ and $\mathrm{Cr}(\mathrm{VI})$, J. Hazard. Mater. 181 (1-3) (2010) 448-454, doi: https://doi.org/10.1016/j.jhazmat.2010.05.031.

9. V. Goetz, O. Pupier, A. Guillot, Carbon dioxide-methane mixture adsorption on activated carbon, Adsorption. 12 (2006) 55-63, doi: https://doi.org/10.1007/s10450-006-0138-z.

10. H. Yi, F. Li, P. Ning, X. Tang, J. Peng, Y. Li, H. Deng, Adsorption separation of $\mathrm{CO}_{2}, \mathrm{CH}_{4}$, and $\mathrm{N}_{2}$ on microwave activated carbon, Chem. Eng. J. 215-216 (2013) 635-642, doi: https:// doi.org/10.1016/j.cej.2012.11.050.

11. A. Rostami, M. A. Anabaz, H. R. E. Gahrooei, M. Arabloo, A. Bahadori, Accurate estimation of $\mathrm{CO}_{2}$ adsorption on activated carbon with multi-layer feed-forward neural network (MLFNN) algorithm, Egypt. J. Petrol. 27 (2018) 65-73, doi: https://doi.org/10.1016/j.ejpe.2017.01.003.

12. E. N. El Qada, S. J. Allen, G. M. Walker, Influence of preparation conditions on the characteristics of activated carbons produced in laboratory and pilot scale systems, Chem. Eng. J. 142 (2008) 1-13, doi: https://doi.org/10.1016/j. cej.2007.11.008.

13. S. Jribi, T. Miyazaki, B. B. Saha, A. Pal, M. M. Younes, S. Koyama, A. Maalej, Equilibrium and kinetics of $\mathrm{CO}_{2}$ adsorption onto activated carbon, Int. J. Heat Mass Transf. 108 (2017) 1941-1946, doi: https://doi.org/10.1016/j.ijheatmasstransfer.2016.12.114.

14. Z. Zhang, W. Zhang, X. Chen, Q. Xia, Z. Li, Adsorption of $\mathrm{CO}_{2}$ on zeolite $13 \mathrm{X}$ and activated carbon with higher surface area, Sep. Sci. Techno. 45 (5) (2010) 710-719, doi: https:// doi.org/10.1080/01496390903571192.

15. Y. Belmabkhout, R. Serna-Guerrero, A. Sayari, Adsorption of $\mathrm{CO}_{2}$ from dry gases on MCM-41 silica at ambient temperature and high pressure. 1: Pure $\mathrm{CO}_{2}$ adsorption, Chem. Eng. Sci. 64 (2009) 3721-3728, doi: https://doi.org/10.1016/j. ces.2009.03.017.

16. B. J. Maring, P. A. Webley, A new simplified pressure/vacuum swing adsorption model for rapid adsorbent screen- ing for $\mathrm{CO}_{2}$ capture applications, Int. J. Greenhouse. Gas. Control. 15 (2013) 16-31, doi: https://doi.org/10.1016/j. ijggc.2013.01.009.

17. K. S. Hwang, S. Y. Gong, W. K. Lee, Adsorption equilibria for hydrogen and carbon dioxide on activated carbon at high pressure up to $30 \mathrm{~atm}$, Kor. J. Chem. Eng. 8 (1991) 148-155, doi: https://doi.org/10.1007/BF02706676.

18. I. Langmuir, The adsorption of gases on plane surfaces of glass, mica and platinum, J. Amer. Chem. Soc. 40 (1918) 1361-1403, doi: https://doi.org/10.1021/ja02242a004.

19. H. Freundlich, Über die adsorption in lösungen, Z. Phys. Chem. 57U (1907) 385-470, doi: https://doi.org/10.1515/ zpch-1907-5723.

20. R. Sips, On the structure of a catalyst surface, J. Chem. Phys. 16 (1948) 490-495, doi: https://doi.org/10.1063/1.1746922.

21. J. Toth, State equations of the solid gas interface layer, Acta Chem. Acad. Hung. 69 (1971) 311-317.

22. D. M. Ruthven, Principles of Adsorption and Adsorption Processes, Wiley, New York, 1984, doi: https://doi.org/10.1002/ aic.690310335.

23. R. T. Yang, Gas Separation by Adsorption Processes, Butterworths, Boston, 1987.

24. D. D. Do, Adsorption Analysis: Equilibria and Kinetics, Imperial College Press, London, 1998, doi: https://doi. org/10.1142/9781860943829.

25. J. A. Schwarz, C. L. Contescu, Surfaces of Nanoparticles and Porous Materials. Vol. 78, Marcel Dekker Inc., New York, 1999, pp. 392, doi: https://doi.org/10.1201/9780824746681.

26. A. L. Myers, J. M. Prausnitz, Thermodynamics of mixed-gas adsorption, A. I. Ch. E. J. 11 (1965) 121-127, doi: https:// doi.org/10.1002/aic.690110125.

27. S. Suwanayuen, R. P. Danner, A gas adsorption isotherm equation based on vacancy solution theory, A. I. Ch. E. J. 26 (1980) 68-76, doi: https://doi.org/10.1002/aic.690260112.

28. S. Suwanayuen, R. P. Danner, Vacancy solution theory of adsorption from gas mixtures, A. I. Ch. E. J. 26 (1980) 76-83, doi: https://doi.org/10.1002/aic.690260113.

29. T. W. Cochran, R. L. Kabel, R. P. Danner, Vacancy solution theory of adsorption using Flory-Huggins activity coefficient equations, A. I. Ch. E. J. 31 (1985) 268-277, doi: https://doi. org/10.1002/aic.690310214.

30. D. M. Ruthven, K. F. Loughlin, K. A. Holborow, Multicomponent sorption equilibrium in molecular sieve zeolites, Chem. Eng. Sci. 28 (1973) 701-709, doi: https://doi. org/10.1016/0009-2509(77)80004-3.

31. D. M. Ruthven, F. Wong, Generalized statistical model for the prediction of binary adsorption equilibria in zeolites, Ind. Eng. Chem. Fund. 24 (1984) 27-32, doi: https://doi. org/10.1021/i100017a005.

32. R. J. Grant, M. Manes, Adsorption of binary hydrocarbon gas mixtures on activated carbon, Ind. Eng. Chem. Fund. 5 (1966) 490-498, doi: https://doi.org/10.1021/i160020a010.

33. M. Hasanzadeh, M. R. Dehghani, F. Feyzi, B. Behzadi, A new simplified local density model for adsorption of pure gases and binary mixtures, Int. J. Thermophys. 31 (2010) 24252439, doi: https://doi.org/10.1007/s10765-010-0827-4.

34. A. Ghosh, P. Das, K. Sinha, Modeling of biosorption of $\mathrm{Cu}$ (II) by alkali-modified spent tea leaves using response surface methodology (RSM) and artificial neural network (ANN), Appl. Water. Sci. 5 (2015) 191-199, doi: https://doi. org/10.1007/s13201-014-0180-z.

35. Z. Shahryari, A. Sharifi, A. Mohebbi, Artificial neural network (ANN) approach for modeling and formulation of phenol adsorption onto activated carbon, J. Eng. Thermo- 
phys. 22 (2013) 322-336, doi: https://doi.org/10.1134/ S181023281304005X.

36. A. B. Bulsari, A. Palosaari, Application of neural networks for system identification of an adsorption column, Neural. Comput. Appl. 1 (1993) 160-165, doi: https://doi.org/10.1007/ BF01414435.

37. K. V. Kumar, M. M. de Castro, M. Martinez-Escandell, M. Molina-Sabio, F. Rodriguez-Reinoso, Neural network and principal component analysis for modeling of hydrogen adsorption isotherms on $\mathrm{KOH}$ activated pitch-based carbons containing different heteroatoms, Chem. Eng. J. 159 (2010) 272-279, doi: https://doi.org/10.1016/j.cej.2010.01.059.

38. C. Cojocaru, M. Macoveanu, I. Cretescu, Peat-based sorbents for the removal of oil spills from water surface: Application of artificial neural network modeling, Colloids. Surf. A. Physicochem. Eng. Asp. 384 (2011) 675-684, doi: https:// doi.org/10.1016\%2Fj.colsurfa.2011.05.036.

39. R. M. Aghav, S. Kumar, S. N. Mukherjee, Artificial neural network modeling in competitive adsorption of phenol and resorcinol from water environment using some carbonaceous adsorbents, J. Hazard. Mater. 188 (2011) 67-77, https://doi. org/10.1016/j.jhazmat.2011.01.067.

40. M. Molashahi, H. Hashemipour, Experimental study and artificial neural network simulation of methane adsorption on activated carbon, Korean. J. Chem. Eng. 29 (2012) 601-605, doi: https://doi.org/10.1007/s11814-011-0215-1.

41. J. P. S. Aniceto, D. L. A. Fernandes, C. M. Silva, Modeling ion exchange equilibrium of ternary systems using neural networks, Desalination 309 (2013) 267-274, doi: https://doi. org/10.1016/j.desal.2012.10.024.

42. M. T. Hagan, H. B. Demuth, M. H. Beale, Neural Network Design, Pws Publ., Boston, 1996.

43. D. Z. Antanasijević, M. Đ. Ristić, A. A. Perić-Grujić, V. V. Pocajt, Forecasting GHG emissions using an optimized artificial neural network model based on correlation and principal component analysis, Int. J. Greenhouse. Gas. Control. 20 (2014) 244-253, doi: https://doi.org/10.1016/j.ijggc.2013.11.011.

44. L. Khaouane, O. Benkortbi, S. Hanini, C. Si-Moussa, Modeling of an industrial process of pleuromutilin fermentation using feed forward neural networks, Braz. J. Chem. Eng. 30 (1) (2013) 105-116, doi: https://doi.org/10.1590/S010466322013000100012.

45. D. S. Lee, J. M. Park, Neural network modeling for on-line estimation of nutrient dynamics in a sequentially-operated batch reactor, J. Biotechnol. 75 (1999) 229-239, doi: https:// doi.org/10.1016/S0168-1656(99)00171-6.

46. R. G. Silva, A. J. G. Cruz, C. O. Hokka, R. L. C. Giordano, R. C. Giordano, A hybrid feedforward neural network model for the cephalosporin C production process, Braz. J. Chem. Eng. 17 (2000) 587-598, doi: https://doi.org/10.1590/S010466322000000400023.

47. M. R. Fagundes-Klen, P. Ferri, T. D. Martins, C. R. G. Tavares, E. A. Silva, Equilibrium study of the binary mixture of cadmium-zinc ions biosorption by the Sargassum filipendula species using adsorption isotherms models and neural network, Biochem. Eng. J. 34 (2007) 136-146, doi: https://doi. org/10.1016/j.bej.2006.11.023.

48. R. C. Deo, M. Şahin, Application of the artificial neural network model for prediction of monthly standardized precipitation and evapotranspiration index using hydrometeorological parameters and climate indices in eastern Australia, Atmospheric. Res.161-162 (2015) 65-81, doi: https://doi. org/10.1016/j.atmosres.2015.03.018.

49. Y. Ammi, L. Khaouane, S. Hanini, Prediction of the rejection of organic compounds (neutral and ionic) by nanofiltration and reverse osmosis membranes using neural networks, Ko- rean J. Chem. Eng. 32 (2015) 2300-2310, doi: https://doi. org/10.1007/s11814-015-0086-y.

50. C. Si-Moussa, S. Hanini, R. Derriche, M. Bouhedda, A. Bouzidi, Prediction of high-pressure vapor liquid equilibrium of six binary systems, carbon dioxide with six esters, using an artificial neural network model, Braz. J. Chem. Eng. 25 (2008) 183-199, doi: https://doi.org/10.1590/S010466322008000100019.

51. M. Carsky, D. D. Do, Neural network modeling of adsorption of binary vapour mixtures, Adsorption. 5 (1999) 183-192, doi: https://doi.org/10.1023/A:1008977528474.

52. V. D. Nguyen, R. R. Tan, Y. Brondial, T. Fuchino, Prediction of vapor-liquid equilibrium data for ternary systems using artificial neural networks, Fluid. Phase. Equilib. 254 (2007) 188-197, doi: https://doi.org/10.1016/j.fluid.2007.03.014.

53. J. E. Schmitz, R. J. Zemp, M. J. Mendes, Artificial neural networks for the solution of the phase stability problem, Fluid Phase Equilib. 245 (2006) 83-87, doi: https://doi. org/10.1016/j.fluid.2006.02.013.

54. F. Dreisbach, R. Staudt, J. U. Keller, High pressure adsorption data of methane, nitrogen, carbon dioxide and their binaryand ternary mixtures on activated carbon, Adsorption. 5 (1999) 215-227, doi: https://doi.org/10.1023/A:1008914703884.

55. M. Sudibandriyo, Z. Pan, J. E. Fitzgerald, R. L. Robinson, K. A. M. Gasem, Adsorption of methane, nitrogen, carbon dioxide, and their binary mixtures on dry activated carbon at 318.2 K and pressures up to 13.6 MPa, Langmuir. 19 (2003) 5323-5331, doi: https://doi.org/10.1021/la020976k.

56. 5R. B. Rios, F. M. Stragliotto, H. R. Peixoto, A. E. B. Torres, M. Bastos-Neto, D. C. S. Azevedo, C. L. Cavalcante Jr, Studies on the adsorption behavior of $\mathrm{CO}_{2}-\mathrm{CH}_{4}$ mixtures using activated carbon, Braz. J. Chem. Eng. 30 (2013) 939-951, doi: https://doi.org/10.1590/S0104-66322013000400024.

57. A. Awadallah-F, S. A. Al-Muhtaseb, Carbon dioxide sequestration and methane removal from exhaust gases using resorcinol-formaldehyde activated carbon xerogel, Adsorption. 19 (2013) 967-977, doi: https://doi.org/10.1007/s10450013-9508-5.

58. Z. Zhang, M. Xu, H. Wang, Z. Li, Enhancement of $\mathrm{CO}_{2}$ adsorption on high surface area activated carbon modified by $\mathrm{N}_{2}, \mathrm{H}_{2}$ and ammonia, Chem. Eng. J. 160 (2010) 571-577, doi: https://doi.org/10.1016/j.cej.2010.03.070.

59. P. Ning, F. Li, H. Yi, X. Tang, J. Peng, Y. Li, D. He, H. Deng, Adsorption equilibrium of methane and carbon dioxide on microwave-activated carbon, Sep. Purif. Technol. 98 (2012) 321-326, doi: https://doi.org/10.1016/j.seppur.2012.07.001.

60. Y. Ben Torkia, M. Ben Yahia, M. Khalfaoui, S. A. Al-Muhtaseb, A. Ben Lamine, Energetic investigation of the adsorption process of $\mathrm{CH}_{4}, \mathrm{C}_{2} \mathrm{H}_{6}$ and $\mathrm{N}_{2}$ on activated carbon: Numerical and statistical physics treatment, Physica. B. Condens. Matter. 433 (2014) 55-61, doi: https://doi.org/10.1016/j. physb.2013.09.057.

61. R. V. D. Vaart, C. Huiskes, H. Bosch, T. Reith, Single and mixed gas adsorption equilibria of carbon dioxide/methane on activated carbon, Adsorption. 6 (2000) 311-323, doi: https://doi.org/10.1023/A:1026560915422.

62. D. Pino, F. Plantier, D. Bessieres, Experimental determination of the adsorption isotherms in gas mixtures under extended pressure and temperature range, J. Therm. Anal. Calorim. 117 (2014) 1469-1477, doi: https://doi.org/10.1007/ s10973-014-3931-z.

63. M. S. Balathanigaimani, H.-C. Kang, W.-G. Shim, C. Kim, J.W. Lee, H. Moon, Preparation of powdered activated carbon from rice husk and its methane adsorption properties, Korean J. Chem. Eng. 23 (2006) 663-668, doi: https://doi. 
org/10.1007/BF02706811.

64. F. Ahmed, H. J. Cho, J. K. Kim, N. U. Seong, Y. K. Yeo, A real-time model based on least squares support vector machines and output bias update for the prediction of $\mathrm{NOx}$ emission from coal-fired power plant, Korean. J. Chem. Eng. 32 (2015) 1029-1036, doi: https://doi.org/10.1007/s11814014-0301-2.

65. L. Khaouane, Etude et modélisation de la biosynthèse des antibiotiques à partir de différentes souches productrices - cas de pleuromutiline, PhD thesis, Université de Médéa, Algeria, 2013.
66. E. M. E. -M. Shokir, E. S. Al-Homadhi, O. Al-Mahdy, A. A.-H. El-Midany, Development of artificial neural network models for supercritical fluid solvency in presence of co-solvents, Korean. J. Chem. Eng. 31 (2014) 1496-1504, doi: https:// doi.org/10.1007/s11814-014-0065-8.

67. H. Adib, S. Hassanajili, M. R. Sheikhi-Kouhsar, A. Salahi, T. Mohammadi, Experimental and computational investigation of polyacrylonitrile ultrafiltration membrane for industrial oily wastewater treatment, Korean. J. Chem. Eng. 32 (2015) 159-167, doi: https://doi.org/10.1007/s11814-014-02189.

\section{SAŽETAK \\ Modeliranje adsorpcije metana, dušika, ugljikova dioksida te njihovih binarnih i ternarnih smjesa na aktivnim ugljenima pomoću umjetne neuronske mreže

\author{
Hadjer Barki, Latifa Khaouane* i Salah Hanin
}

$\mathrm{U}$ ovom radu ispitana je primjena neuronskih mreža u modeliranju procesa adsorpcije smjese plinova $\left(\mathrm{CO}_{2}, \mathrm{CH}_{4}\right.$ i $\left.\mathrm{N}_{2}\right)$ na različitim aktivnim ugljenima. Izrađeno je sedam modela neuronskih mreža, karakteriziranih različitim strukturama s ciljem predviđanja adsorpcije smjesa plinova. Za testiranje neuronskih mreža primijenjen je skup od 417, 625, 143, 87, 64, 64 i 40 podatkovnih točaka za NN1 do NN7. Od ukupnih podataka $60 \%$, 20 \% i $20 \%$ rabljeno je za obuku, validaciju i testiranje sedam modela. Rezultati pokazuju dobar odnos predviđenih i eksperimentalnih vrijednosti za svaki model; pronađene su dobre korelacije $(R=0,99656$ za NN1, $R=0,99284$ za NN2, $R=0,99388$ za NN3, $R=0,99639$ za $Q_{1}$ za NN4, $R=0,99472$ za $Q_{2}$ za NN4, $R=0,99716$ za $Q_{1}$ za NN5, $R=0,99972$ za $Q_{3}$ za NN5, $R=0,99746$ za $Q_{2}$ za NN6, $R=0,99783$ za $Q_{3}$ za NN6, $R=0,9946$ za $Q_{1}$ za NN7, $R=0,99089$ za $Q_{2}$ za NN7 i $R=0,9947$ za $Q_{3}$ za NN7). Dodatno, usporedba predviđenih rezultata i klasičnih modela (Gibbsov model, generalizirani Langmuirov model i teorija idealne adsorpcije otopine) pokazuje da su modeli neuronskih mreža dali daleko bolje rezultate.

Ključne riječi

Aktivni ugljen, adsorpcija, smjesa plinova, modeliranje, neuronske mreže

Laboratory of Biomaterial and Transport

Phenomena (LBMPT),

University of Médéa,

Alžir
Izvorni znanstveni rad Prispjelo 18. siječnja 2019 Prihvaćeno 8. ožujka 2019. 